\title{
Adenoviral-mediated Gene Transfer to Fetal Pulmonary Epithelia In Vitro and In Vivo
}

\author{
Paul B. McCray, Jr., ${ }^{\star}$ Kelly Armstrong, ${ }^{\star}$ Joseph Zabner, ${ }^{\ddagger}$ Daniel W. Miller, ${ }^{\ddagger}$ Gary A. Koretzky, ${ }^{\ddagger}$ Larry Couture, ${ }^{5}$ \\ Jean E. Robillard, * Alan E. Smith, ${ }^{\mathbb{\$}}$ and Michael J. Welsh ${ }^{\star}$ \\ Department of $*$ Pediatrics and Departments of ${ }^{\ddagger}$ Internal Medicine and Physiology and Biophysics, Howard Hughes Medical Institute, \\ University of Iowa College of Medicine, Iowa City, Iowa 52242; and ${ }^{\S}$ Genzyme Corporation, Framingham, Massachusetts 01701
}

\begin{abstract}
Vector-mediated gene transfer offers a direct method of correcting genetic pulmonary diseases and might also be used to correct temporary abnormalities associated with acquired, nongenetic disorders. Because the fetus or newborn may be a more immune tolerant host for gene transfer using viral vectors, we used replication defective recombinant adenoviral vectors to test the feasibility of gene transfer to the fetal pulmonary epithelium in vitro and in vivo. Both proximal and distal epithelial cells in cultured fetal lung tissues from rodents and humans diffusely expressed the lacZ transgene 3 d after viral infection. In vivo gene delivery experiments were performed in fetal mice and lambs. Delivery of Ad2/CMV- $\beta$ Gal to the amniotic fluid in mice produced intense transgene expression in the fetal epidermis and amniotic membranes, some gastrointestinal expression, but no significant airway epithelial expression. When we introduced the adenoviral vector directly into the trachea of fetal lambs, the lac $Z$ gene was expressed in the tracheal, bronchial, and distal pulmonary epithelial cells $3 \mathrm{~d}$ after viral infection. Unexpectedly, reactive hyperplasia and squamous metaplasia were noted in epithelia expressing lacZ in the trachea, but not in the distal lung of fetal lambs. 1 wk after infection, adenovirus-treated fetuses developed inflammatory cell infiltrates in the lung tissue with CD4, CD8, IgM, and granulocyte/macrophage positive immune effector cells. Transgene expression faded coincident with inflammation and serologic evidence of antiadenoviral antibody production. While these studies document the feasibility of viral-mediated gene transfer in the prenatal lung, they indicate that immunologic responses to E1-deleted recombinant adenoviruses limit the duration of transgene expression. (J. Clin. Invest. 1995. 95:2620-2632.) Key words: gene therapy • adenovirus $\cdot$ fetus $\bullet$ CFTR $\bullet$ immune response

\section{Introduction}

Several recent studies support the feasibility of viral vectormediated gene transfer to epithelial tissues as an approach to the

Address correspondence to Paul B. McCray, Jr., Department of Pediatrics, University of Iowa College of Medicine, Iowa City, IA 52242. Phone: 319-356-4866; FAX: 319-353-6217.

Received for publication 28 March 1994 and in revised form 22 February 1995.

J. Clin. Invest.

(C) The American Society for Clinical Investigation, Inc.

0021-9738/95/06/2620/13 \$2.00

Volume 95, June 1995, 2620-2632 treatment of genetic diseases. Examples include gene transfer to pulmonary epithelial cells to treat cystic fibrosis (CF) ${ }^{1}$ (13 ) and $\alpha$-1-antitrypsin deficiency (4), and gene delivery to hepatocytes as an approach to correct CF liver disease and hemophilia $(5,6)$. The recombinant adenovirus Ad2/CFTR-1 was successfully used to transfer CFTR cDNA to the human nasal epithelium in vivo (7). Most gene transfer studies have focused on adult animals or humans and current trials of gene transfer for CF are being performed in adults. Recently, it has been reported that immunologic responses limit the duration of adenoviral-mediated gene expression $(8,9)$. Stimulation of both the humoral and cellular immune systems has been noted with these vectors $(8,10)$. Studies of gene transfer to the liver using MHC class I-deficient mice suggest that cytotoxic $\mathrm{T}$ lymphocyte responses to recombinant viral protein expression may limit the clinical utility of current E1-deleted adenoviral vectors (11).

One exception to the immunologic responses noted above is a report of long-term transgene expression in skeletal and cardiac muscle after adenoviral-mediated gene transfer in neonatal mice (12). These findings suggest that the fetus or newborn may be a more immune tolerant host for gene transfer using recombinant adenoviruses. In addition, there may be a number of indications for gene transfer to the fetus or neonate. For example, if a genetic abnormality is associated with the early onset or progression of disease, then gene transfer in the prenatal or neonatal period may be indicated. Because genetic diagnostic testing now allows for the accurate genotyping of fetuses with many inherited disorders, an increasing number of prenatal diagnoses raise issues of prenatal treatment. In addition, gene transfer may have applications for the perinatal or neonatal treatment of acquired disorders such as neonatal respiratory distress syndrome and surfactant deficiency syndromes. Finally, gene transfer may provide a research tool to study the developmental regulation of genes introduced into the fetal lung and other organs.

Recombinant adenoviruses offer an attractive means for transferring genes into mammalian pulmonary epithelial cells because of their high efficiency. We asked whether an adenovirus vector might be used to introduce genes into the pulmonary epithelium prenatally. We specifically tested the hypothesis that the fetus is an immune tolerant host for adenoviral-mediated gene transfer to the lung and therefore unlikely to mount an immunologic response to recombinant adenoviral vectors.

\section{Methods}

Adenovirus vector. Construction, preparation, and titering of the recombinant adenoviruses Ad2/CMV- $\beta$ Gal and Ad2/CFTR-2 have been re-

1. Abbreviations used in this paper: $\mathrm{CF}$, cystic fibrosis; Dil, 1,1-dioctadecyl-3,3,3',3'-tetramethylindocarbocyanine perchlorate; PGK, phosphoglycerate kinase; RT, reverse transcriptase; SP, surfactant protein. 
ported $(1,13)$. In $A d 2 / C M V-\beta G a l$, the viral early region 1 coding sequences $\mathrm{E} 1 \mathrm{a}$ and $\mathrm{E} 1 \mathrm{~b}$ are replaced with the Escherichia coli lacZ gene driven by the CMV promoter. The vector retains the E3 region. Transgene expression is localized to the nucleus because a nuclear localization signal has been fused to $\beta$-galactosidase. The phosphoglycerate kinase (PGK) promoter is used in Ad2/CFTR-2. The viral constructs are replication defective and are grown in the human embryonal kidney 293 cell line that complements the viral E1 gene products. Cells are freeze/thawed three times to release the virus, and the preparation is then purified on a $\mathrm{CsCl}$ gradient and dialyzed against PBS and $1 \%$ sucrose to remove $\mathrm{CsCl}$ as described previously (1).

Viral assays. Viral cultures were performed on the permissive 293 cells or on HeLa cells as described previously (1). Serial dilutions of amniotic fluid were added in duplicate to 293 cells grown in 96-well plates at $50 \%$ confluence. The 293 cells were incubated for $72 \mathrm{~h}$ at $37^{\circ} \mathrm{C}$, then fixed with a $1: 1$ mixture of methanol and acetone for 10 min and incubated with an FITC-labeled antiadenovirus monoclonal antibody (Chemicon International, Inc., Temecula, CA) for $30 \mathrm{~min}$. Positive nuclear immunofluorescence was noted as a positive culture indicating expression of viral proteins. To test for production of replication competent virus or contamination by wild-type adenovirus, HeLa cell cultures, which support the growth of wild-type, but not E1-deleted adenovirus, were treated with aliquots of amniotic fluid and assayed for viral protein production.

Microscopy. Histochemistry was used to identify cells expressing the $E$. coli lacZ gene as described previously (1). The left mainstem bronchus was ligated and the left lung was excised and frozen at $-70^{\circ} \mathrm{C}$ for use in immunohistochemistry studies or for PCR. The trachea and remaining lung tissue were fixed by instillation with $2 \%$ paraformaldehyde and $0.02 \%$ gluteraldehyde in PBS for $1 \mathrm{~h}$, rinsed twice with PBS, and then incubated overnight in the X-gal reagent (5-bromo-4-chloro-3indolyl- $\beta$-D-galactopyranoside) at room temperature. 8 - $\mu \mathrm{m}$-thick frozen sections were prepared from tissues embedded in OCT compound (Tissue-Tek; Miles Inc., Kankakee, IL). Alternatively, some fixed tissues were embedded in glycomethacrylate using standard techniques, and 2$4-\mu \mathrm{m}$-thick sections were prepared. LacZ-positive cells stain blue; the predominant staining is nuclear as the nuclear localization signal directs lacZ expression to the nucleus. Sections were examined to assess the surface epithelium cell types susceptible to adenoviral gene transfer (ciliated, nonciliated, basal) and for evidence of gene transfer to submucosal glands. Some specimens were fixed and embedded for transmission electron microscopy using standard techniques to document the nuclear localization of the gene product. We also looked for evidence of inflammation after viral infection by examining hematoxylin and eosinstained sections for the presence of inflammatory cell infiltrates and by performing immunohistochemistry. For each experimental or littermate control animal, two to four tissue blocks from areas of the trachea (proximal, middle, and distal) and each lobe of the right lung (apical, middle, diaphragmatic, and accessory) were examined histochemically. Hematoxylin and eosin sections were scored for inflammation semiquantitatively from 0 to $4+$. Sections were also examined by two pathologists unaware of the treatment the animals received.

To quantify transgene expression, we studied X-gal-stained, plasticembedded sections from the trachea and lung tissue of the eight animals that received Ad2/CMV- $\beta$ Gal. Differential cell counts were performed at three levels of the trachea (proximal, middle, and distal) and two lobes of the right lung (apical and diaphragmatic). Sections were selected randomly from the same site in each animal and examined under oil immersion at a magnification of 1,000 to determine the number of $\beta$ Gal-positive epithelial cells. 2,000 cells were counted from each region, and the percentage of $\beta \mathrm{Gal}$-positive cells per 2,000 cells was determined. The mean percentage and range of $\beta \mathrm{Gal}$-positive cells between the tracheal regions and lung regions were also calculated. Only cells with visible nuclei were counted. If glycomethacrylate sections showed no evidence of transgene expression, frozen sections from the same anatomic site were examined to confirm the finding.

Immunohistochemistry. To characterize the immunologic response to adenoviral-mediated gene transfer in the lung, we performed immuno- histochemistry using specific monoclonal antibodies against sheep IgM, CD4, CD8, and granulocyte/macrophage markers. $1 \times 1 \mathrm{~cm}$ pieces of lung tissue were embedded in OCT compound and immediately frozen in liquid nitrogen. 6- $\mu \mathrm{m}$ serial cryostat sections were placed on Superfrost Plus microscope slides (Fisher Scientific Co., Pittsburgh, PA) and allowed to dry overnight at room temperature before being fixed in ice-cold acetone for $5 \mathrm{~min}$ and air dried. Samples were then dehydrated at $37^{\circ} \mathrm{C}$ for $30 \mathrm{~min}$ with $50 \mathrm{mM}$ glycine in PBS, changing the solution every $10 \mathrm{~min}$. Rehydrated samples were blocked with $100 \mu \mathrm{l}$ casein ( $1 \% \mathrm{wt} / \mathrm{vol}$ in PBS, Hammersten grade; Pierce, Rockford, IL) for $1 \mathrm{~h}$ at $37^{\circ} \mathrm{C} .50 \mu \mathrm{l}$ of the primary antibody was then diluted in casein and placed on top of the sample and incubated overnight at $4^{\circ} \mathrm{C}$. The following IgG isotype antibodies and dilutions were used: mouse myeloma protein (MOPC) 1:10-1:640 (1.0 mg/ml stock; Cappel Laboratories, Cochranville, PA), mouse anti-sheep IgM at 1:100 (1.0 mg/ml stock; Veterinary Medical Research and Development, Pullman, WA) (14), mouse anti-sheep CD4 at 1:10 (hybridoma supernatant, undiluted) (15), mouse anti-sheep CD8 at $1: 640(1.0 \mathrm{mg} / \mathrm{ml}$ stock; Veterinary Medical Research and Development ) (16), and mouse anti-sheep granulocyte macrophage at 1:100 $(1.0 \mathrm{mg} / \mathrm{ml}$ stock; Veterinary Medical Research and Development) (14). After incubation the sample slides were washed in PBS at $4^{\circ} \mathrm{C}$ for $10 \mathrm{~min}$. Sheep anti-mouse IgG conjugated to Cy3 (1.5 mg/ml stock; Jackson ImmunoResearch Laboratories, Inc., West Grove, PA) was diluted at 1:400 in casein, and $50 \mu \mathrm{l}$ was applied to each sample. Samples were subsequently incubated at room temperature for $1 \mathrm{~h}$ and washed as above. Slides were then cover slipped using Aqua-Mount (Lerner Laboratories, New Haven, CT) and viewed under fluorescent light between 546 and $590 \mathrm{~nm}$. MOPC, a nonspecific monoclonal antibody against mouse myeloma protein, was used as a negative control with dilutions that matched the specific antibodies. Adult sheep lymph nodes were used as a positive control.

Reverse transcriptase ( $R T)$-PCR. We used RT-PCR to detect vector-generated mRNA in lung tissues from fetal lambs as described previously (10). Primers were similar to those reported previously with the exception of the substitution of promoter-specific sequences as follows: PGK 5' CGG AGC GCA CGT CGG CAG TCG G 3', PGK 5' GCT CCC TCG TTG ACC GAA TCA CCG ACC $3^{\prime}(10,13)$. Lung samples were snap frozen in liquid nitrogen and stored at $-70^{\circ} \mathrm{C}$ until used. Total RNA was isolated using the single-step chloroform/phenol extraction method, and $2 \mu \mathrm{l}$ of RNA was reverse transcribed using the GeneAmp RNA PCR kit (Perkin-Elmer Corp., Norwalk, CT) (17). For a negative control, reverse transcriptase was omitted from the reaction mixture. A $10-\mu \mathrm{l}$ aliquot of the PCR product was electrophoresed on a $1 \%$ agarose gel and visualized with ethidium bromide.

In vitro models. 12-13-d gestation fetal rat lung explants were grown in culture using methods similar to those described previously (18). Timed pregnant (sperm positive $=$ day 0 ) Sprague-Dawley rats were killed with $\mathrm{CO}_{2}$ inhalation, and the fetuses were removed by hysterotomy and placed in sterile Hanks' balanced salt solution at $4^{\circ} \mathrm{C}$. Fetal lungs were removed and placed in 35-mm tissue culture dishes precoated with $0.8 \mathrm{ml}$ of Waymouth's media with $1 \%$ FCS and $100 \mathrm{U} / \mathrm{ml}$ penicillin $/ 100 \mu \mathrm{g} / \mathrm{ml}$ streptomycin. After overnight incubation at $37^{\circ} \mathrm{C} / 5 \%$ $\mathrm{CO}_{2}$ in air, during which the tissues adhered to the dishes, the samples were placed on a rocking platform at 3 oscillations $/ \mathrm{min}$. The media were changed daily. Similar experiments were performed with cultured explants of midgestation human fetal lung as previously described (19).

The adenoviral vector (Ad2/CMV- $\beta \mathrm{Gal}, 2 \times 10^{10} \mathrm{IU} / \mathrm{ml}$ ) was introduced into the lumen of fetal lung tissue explants via a micropipette and a pressure-driven apparatus (Picospritzer; General Valve Corp., Fairfield, NJ). From 0.5 to $4 \mu \mathrm{l}$ of virus $\left(10^{7}-8 \times 10^{7} \mathrm{IU}\right)$ was injected into each explant ( $n=32$ rat and 48 human explants). The exact volume delivered is approximate, as some viral suspension always leaked from the injection sites. $3 \mathrm{~d}$ after the injection, tissues were fixed and stained with X-gal.

In vivo models. We used techniques of in utero manipulation of the mouse embryo to introduce either a labeling dye or recombinant adenovirus into the amniotic fluid $(20,21)$. To test the feasibility of this method of gene delivery to the lung, 5-50 $\mu \mathrm{l}$ of $2 \%$ fast green 
dye (Sigma Immunochemicals, St. Louis, MO) or the fluorescent dye 1,1-dioctadecyl-3,3,3',3'-tetramethylindocarbocyanine perchlorate (DiI; Molecular Probes, Inc., Eugene, OR) was introduced into the amniotic cavity (22). DiI was prepared as a $0.5 \%$ solution in $100 \%$ ethanol, diluted $1: 100$ in $0.3 \mathrm{M}$ sucrose and warmed to $37^{\circ} \mathrm{C}$ before injection. 24-72 $\mathrm{h}$ later, the animals were killed, and fetal tissues were examined for rhodamine fluorescence. Similar methods were then used to introduce Ad2/CMV- $\beta$ Gal into the amniotic cavity.

Fetal lamb surgical procedures were performed under sterile conditions using previously described techniques (23). 18 lambs of 90-110 $\mathrm{d}$ of gestation were used in these experiments (term $=145 \mathrm{~d}$ ); each experiment used twin gestations with gestational ages determined based on the induced ovulation technique (23). Two methods were used to introduce the viral suspension into the lung. Briefly, the ewe was fasted $24 \mathrm{~h}$ before surgery and anesthetized using mixtures of halothane (1\%), oxygen $(33 \%)$, and nitrous oxide $(66 \%)$. Under sterile conditions, the uterus was opened over the fetal head, and the head and neck of the fetus were exteriorized. In 17 animals a tracheotomy was performed, and a 5 French balloon-tipped catheter was inserted into the trachea and inflated. Ad2/CMV- $\beta$ Gal (six animals $1 \times 10^{10} \mathrm{IU}$, two animals $3 \times 10^{10} \mathrm{IU}$ ), Ad2/CFTR-2 (three animals $1 \times 10^{10} \mathrm{IU}$, two animals $3 \times 10^{10} \mathrm{IU}$ ), or normal saline (five animals) was mixed in 2 or 20 $\mathrm{ml}$ of normal saline and injected into the lower trachea of 17 fetuses through the catheter. This dose was extrapolated from a previous safety and efficacy study in cotton rats and was expected to transduce a significant number of epithelial cells (10). The balloon catheter was deflated $3 \mathrm{~h}$ after the virus was instilled. In one animal, the head and neck were exteriorized, the thyroid cartilage was identified, and $1 \times 10^{10} \mathrm{IU}$ of Ad2/CMV- $\beta$ Gal was injected into the tracheal lumen through a needle. The fetuses were then returned to the uterus. Animals were killed at intervals of 3 ( 8 animals ), 4 ( 2 animals ), 7 ( 2 animals ), 8 ( 4 animals ), and 14 ( 2 animals) d postoperatively, and the lungs were fixed and stained with X-gal. Catheters were also placed in the amniotic cavity in 5 3-and 4-d experiments to sample the amniotic fluid to test for the presence of infectious virus during the experimental period. Samples of amniotic fluid were collected at $0,24,48,72$, and $96 \mathrm{~h}$ after adenoviral infection. In the 7-, 8-, and 14-d studies amniotic fluid samples were obtained at the beginning and end of the experiments.

\section{Results}

\section{In vitro gene transfer to fetal lungs}

Organ cultures have been used as model systems to study the developing lung because many aspects of their morphology and function parallel in vivo development. Therefore we tested the ability of an adenoviral vector to transfer a gene to fetal rat and human lung in organ culture. $3 \mathrm{~d}$ after injection of Ad2/CMV$\beta \mathrm{Gal}, \mathrm{X}$-gal-stained fetal rat lung tissues showed evidence of both diffuse and patchy epithelial cell lacZ gene expression (Fig. 1, $A, C$, and $D$ ). In some sections virtually all epithelia stained blue, whereas in other areas lacZ expression was patchy. Sites far removed from the point of injection expressed little or no transgene. These findings probably reflect the unequal distribution of injected virus within the fluid-filled airway lumen. Occasionally we saw blue-stained cells in the mesenchyme. LacZ expression in nonepithelial cells probably represents areas exposed to the virus when the micropipette was inserted, as it was not always possible to selectively inject virus into the lumen alone. LacZ-expressing epithelial cells included those in the conducting airways and the distal lung. Noninjected tissues showed no evidence of endogenous $\beta$-galactosidase activity or blue stained nuclei (Fig. $1 B$ ).

To determine if the adenoviral vector would also direct gene expression in the human fetal pulmonary epithelium, we studied second trimester lung tissue in explant culture. Epithelial cells in cultured midgestation human fetal lung tissue explants showed widespread evidence of $\beta$-galactosidase activity $3 \mathrm{~d}$ after injection of virus (Fig. 1, $E$ and $F$ ). Nonciliated cuboidal epithelial cells lining the acinar tubules expressed the lac $Z$ gene. These cells include type II cells and their glycogen-rich precursors (24). These in vitro studies indicate that the adenoviral vector can transfer a cDNA to murine and human fetal pulmonary epithelia and direct expression of recombinant protein.

\section{In vivo gene transfer to fetal lungs}

Fetal mice. The most simple approach to deliver a vector to fetal pulmonary airways would be to introduce the vector into the amniotic fluid. We hypothesized that fetal breathing activity might allow the vector access to the fetal lung (25). To test this possibility, we first developed the in utero techniques of amniotic cavity injection by introducing $2 \%$ fast green dye into the amnions of fetal mice using a micropipette attached to a syringe. With this approach we successfully stained the amniotic cavity in $\sim 60 \%$ of the fetuses (data not shown). Therefore the amniotic cavities of 15-d gestation fetal mice were injected with 5-50 $\mu \mathrm{l}$ of DiI. Examination of the fetuses 24-72 h later revealed diffuse epithelial cell staining of the pulmonary (Fig. $2, A-D)$ and gastrointestinal tracts. Fluorescent staining was also present in the epidermis but not in other fetal organs. The pulmonary epithelial cell staining extended from the trachea to the distal acinar tubules (Fig. 2, A-D). These observations indicate that the marker dye in amniotic fluid reached the pulmonary epithelium, possibly during episodes of fetal breathing with the glottis open.

The preliminary experiments with dyes suggested that a vector introduced into amniotic fluid might reach pulmonary epithelial cells. In subsequent experiments 5-50 $\mu$ l of viral suspension was injected into the amniotic cavities of 15 -d gestation mouse embryos. $2 \mathrm{~d}$ later the fetuses were removed and fixed and stained with X-gal. While this approach achieved abundant lacZ gene expression in the skin, oropharynx, and, to a lesser extent, the gastrointestinal tract of the fetus, we saw no significant staining of the pulmonary epithelium ( $n=10$, Fig. $2, E$ and $F$ ). Control, untreated animals showed no blue-stained cells. The lack of pulmonary cell labeling in virus-treated fetuses suggests that diffuse infection of the fetal epidermal and amniotic membrane surfaces may have significantly reduced the amniotic fluid viral titer and thus decreased the amount of virus that could be transferred to the lung. Alternatively, the diffusion and flow of the virus may have been more restricted than the smaller dyes. Therefore we examined the effect of direct instillation of virus into the fetal airway.

Fetal lambs. The fetal lamb was used for these in vivo studies because its large size allowed easy manipulation and direct introduction of the vector into the fetal lung through ex utero approaches. Furthermore, submucosal glands develop prenatally in the lamb, as in humans, and lung development proceeds at a slower rate compared with other nonprimates. Fetal lambs of $90-110-d$ gestation were studied to test the hypothesis that a vector introduced into lung fluid could infect the epithelium in vivo. As shown in Figs. 3 and 4, $3 \mathrm{~d}$ after gene transfer blue-stained cells were evident in the trachea, conducting airways, and the distal lung epithelium of the virustreated fetuses. The distribution of transgene-expressing cells was variable. Pronounced tracheal epithelium staining was seen in animals in which the virus was instilled with $2 \mathrm{ml}$ of saline (Table I). The percentage of $\beta \mathrm{Gal}$-positive tracheal cells ranged 

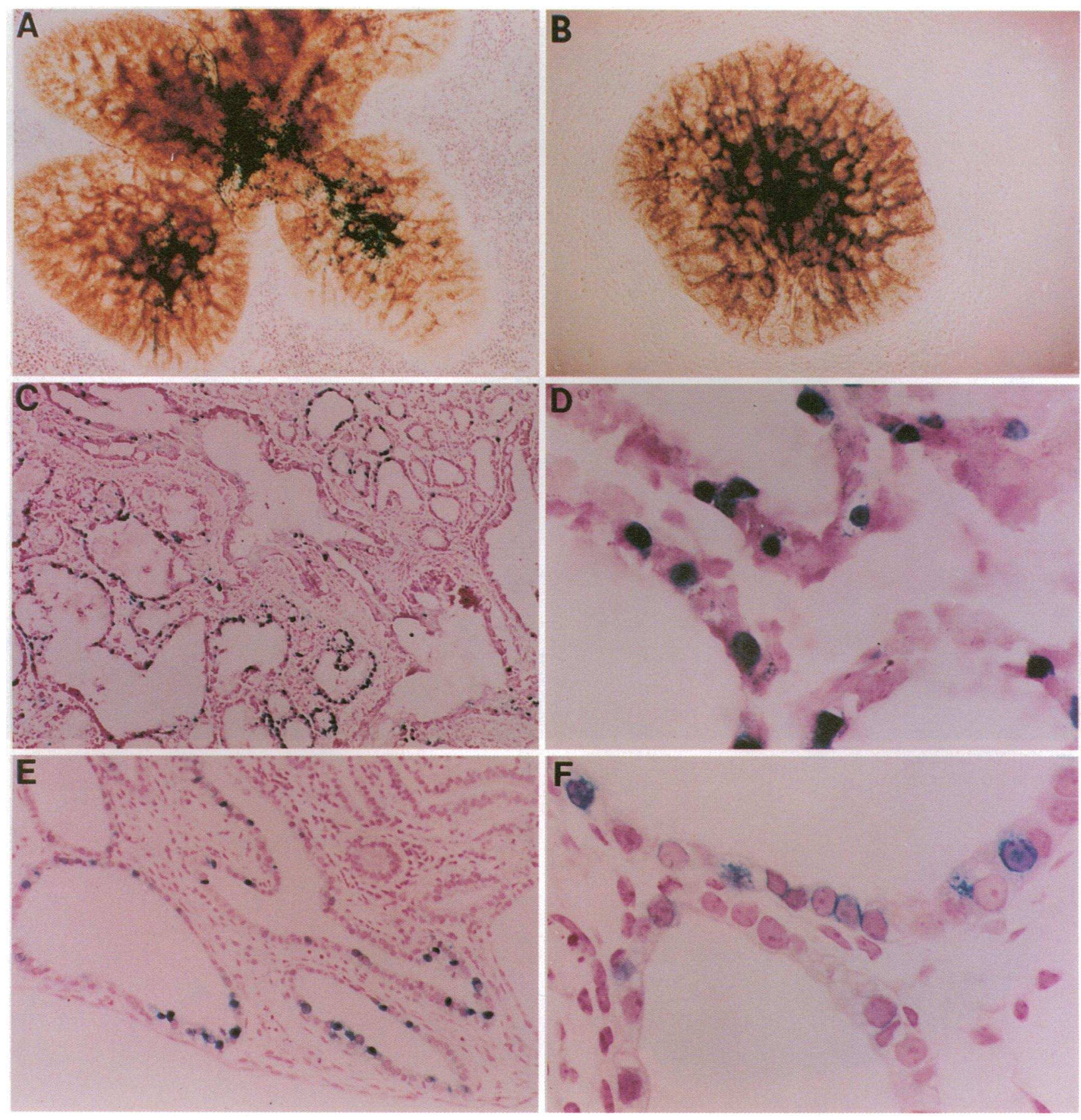

Figure 1. LacZ gene expression in cultured fetal lung tissues $72 \mathrm{~h}$ after infection with Ad2/CMV- $\beta$ Gal. $(A)$ Wholemount view of cultured fetal rat lung explant shows multiple areas of blue-staining cells within the lung, $\times 40$. (B) Fetal rat lung explant, wholemount of control, noninjected tissue, $\times 40$. No endogenous $\beta$-galactosidase activity is noted. $(C)$ Cryosection of fetal rat lung explant showing blue-stained epithelia in both conducting airways and distal epithelial cells, $\times 100$. $(D)$ Cryosection of fetal rat lung explant demonstrating multiple X-gal-positive epithelial cells, $\times 1,000$. Occasional positive cells were seen in the mesenchyme. $(E)$ Photomicrograph of glycomethacrylate-embedded sections of midgestation human fetal lung explants injected with Ad2/CMV- $\beta \mathrm{Gal}$ and fixed and stained with $\mathrm{X}$-gal $3 \mathrm{~d}$ later, $\times 200$. Transgene expression is present in the cuboidal epithelial cells lining the acinar tubules of explants. $(F)$ Higher magnification view of specimen from $E$ demonstrates nuclear localized lacZ expression in the nonciliated epithelial cells, $\times 1,000$.

from $<1 \%$ to $28 \%$ with the $2-\mathrm{ml}$ instillation volume. In contrast, when the instillation volume was increased to $20 \mathrm{ml}$, more distal lung cell expression was evident (Fig. 4, $E$ and $F$; Table I). The percentage of $\beta \mathrm{Gal}$-positive cells was greater in the lungs in which the virus was instilled through a catheter with the balloon inflated than when the virus was introduced by transtracheal injection (Table I). Microscopically, blue staining was nuclear and localized to epithelial cells. To verify that the histochemical pattern was consistent with transgene expression we also performed electron microscopy. The nuclear localization of the lacZ gene product was confirmed using transmission electron microscopy (not shown). There was no endogenous 

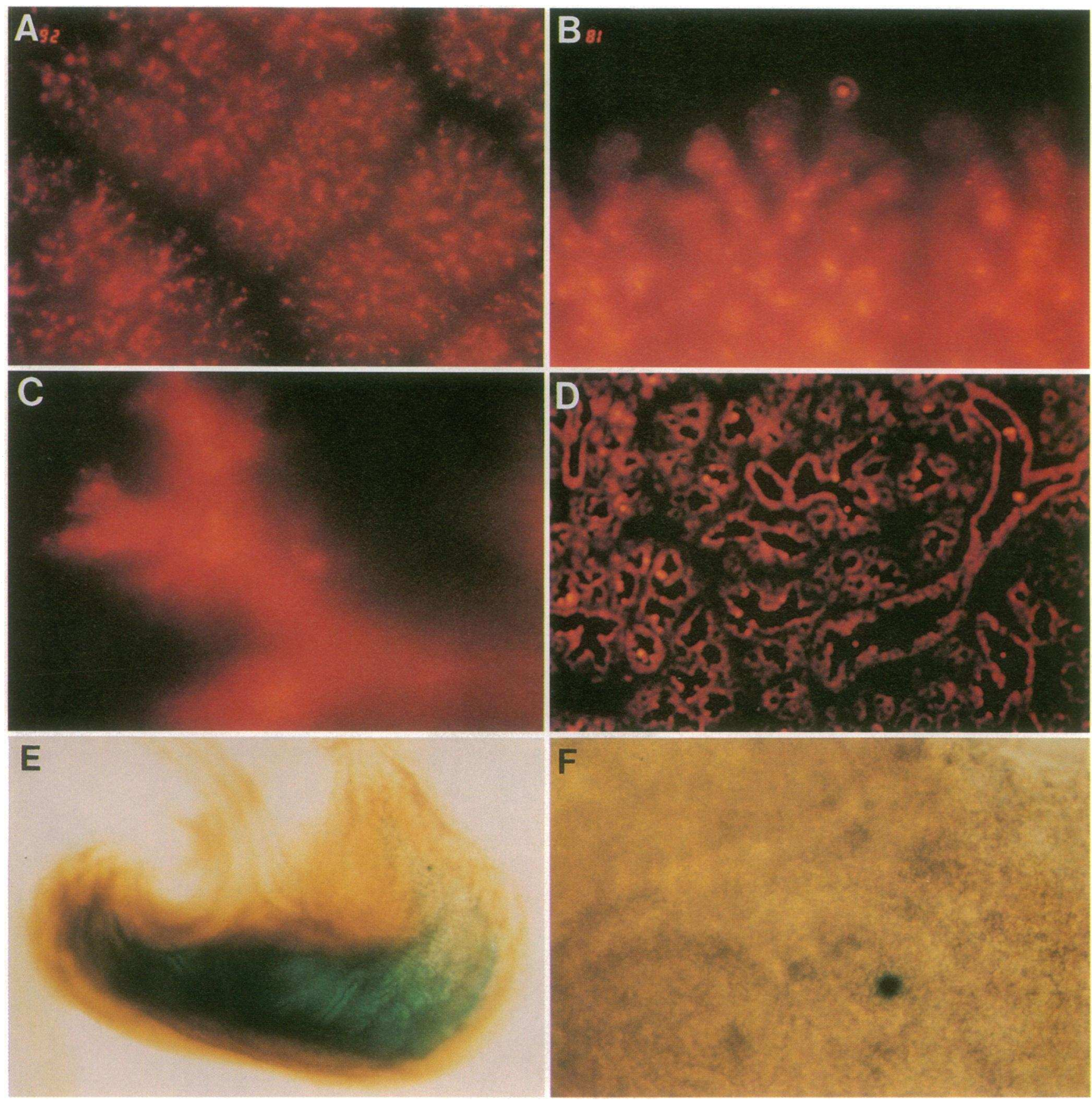

Figure 2. In vivo amniotic injections of 15-d gestation fetal mice. $(A)$ Wholemount of lung from 15-d gestation mouse $48 \mathrm{~h}$ after injection of DiI into the amniotic cavity. Fluorescent epithelial cells are visualized in the conducting airways and distal pulmonary epithelium, $\times 160$. $(B)$ Wholemount of lung from $A$ demonstrating fluorescent cells in the distal pulmonary epithelium, $\times 400$. $(C)$ Wholemount of lung from $A$ showing fluorescent epithelial cells at the end of the acinar tubule, $\times 1,000$. (D) Cryosections of lung tissue from DiI-injected amnion documents that the fluorescent signal is specific to the epithelia, $\times 160$. Control fetuses showed no fluorescence in the pulmonary epithelium. $(E)$ Wholemount of stomach from fetus $72 \mathrm{~h}$ after amniotic injection of Ad2/CMV- $\beta \mathrm{Gal}, \times 40$. Diffuse blue staining of the stomach lining is seen. $(F)$ wholemount of lung from fetus $72 \mathrm{~h}$ after amniotic injection of Ad2/CMV $-\beta \mathrm{Gal}, \times 100$. A single cluster of positive cells was observed.

$\beta$-galactosidase activity in the littermate control fetal lung. In addition to transgene expression in the lungs, blue-staining cells were also noted on the fetal amniotic membranes, oropharynx and tongue, esophagus, stomach, and small intestine at 3 and 4 $\mathrm{d}$ after instillation of virus into the lung (not shown). This is similar to the findings observed in the fetal mice experiments and is not surprising in view of the fact that the fetus swallows significant volumes of amniotic fluid (26).

Examination of $\beta$-galactosidase-positive cells in the tracheas of fetal lambs showed transgene expression in both surface cells and basally located cells including ciliated, nonciliated, and basal cell types (Fig. 4). Therefore, the virus directed 

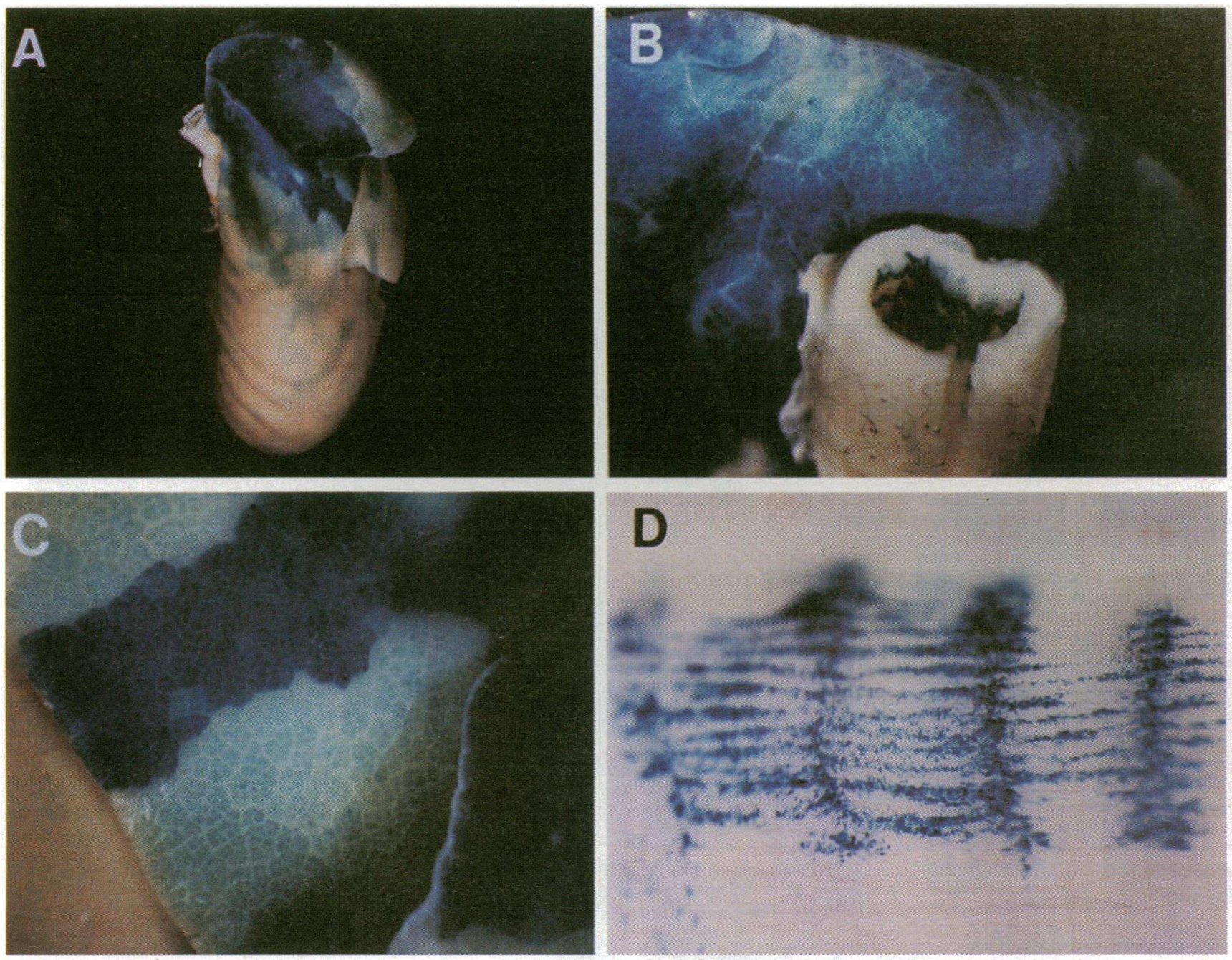

Figure 3. Views of fetal lamb lung fixed and X-gal-stained en bloc $3 \mathrm{~d}$ after instillation of Ad2/CMV- $\beta$ Gal through a tracheal catheter with 20 $\mathrm{ml}$ of saline. $(A)$ View of right lung showing variable blue staining visible at the pleural surface of the lung. $(B)$ View of trachea and adjacent lung tissue showing abundant transgene expression. $(C)$ Variable degrees of blue cell staining at the lung surface at higher magnification. The lobules of the lung can be differentiated. $(D)$ Blue staining tracheal epithelial cells.

transfer of the reporter gene to all cell types of the tracheal epithelium. We did not observe blue-stained nuclei in subepithelial cells.

In regions of the trachea where the transgene was expressed, epithelial cells were noted to exhibit variable morphology (Fig. 4). In areas where lacZ-expressing cells were infrequent or absent, the normal columnar epithelium with pseudopalisading was preserved. However, in the areas where a greater number of cells expressed the transgene, reactive changes were noted in the epithelium. These changes included areas of reactive hyperplasia and squamous metaplasia with loss of the normal morphology (Fig. 4, $B-D$ ). In these areas the columnar epithelium was replaced with stratified squamous epithelial cells and there was a loss of cilia (Fig. $4 \mathrm{D}$ ). The morphologic changes were only noted in the areas where lacZ expression was observed. These changes were found in the trachea of the animal in which the virus was introduced through a needle and in the trachea of catheterized animals below the level of the catheter tip. Therefore these alterations do not appear to be due to mechanical injury of the trachea. This pattern was not observed in areas that did not show blue-stained cells or in littermate control animals that received saline.

We also were interested in whether fetal submucosal gland cells were accessible to gene transfer using this technique. Localization studies of CFTR mRNA and protein expression have shown that levels of expression in submucosal glands are greater than in the surface epithelium, suggesting that gene transfer to both the surface epithelium and submucosal glands may be important therapeutically (27). Occasional blue cells were seen in the apical lining cells of the submucosal glands but not in the deeper portions of the gland structure. Transgene expression was also seen in the nonciliated cuboidal epithelial cells of the distal pulmonary epithelium of the pseudoglandular stage lung, especially in the animals that received the $20-\mathrm{ml}$ volume of instillate (Fig. 4, $E$ and $F$; Table I). When the virus was instilled with 20 -ml volumes, the percentage of $\beta \mathrm{Gal}$-positive distal pulmonary epithelial cells ranged from 1 to $12 \%$ (Table I).

Because prenatal gene transfer to the lung is potentially relevant to the treatment of human disease, we also tested the ability of the adenoviral vector to transfer the human CFTR 

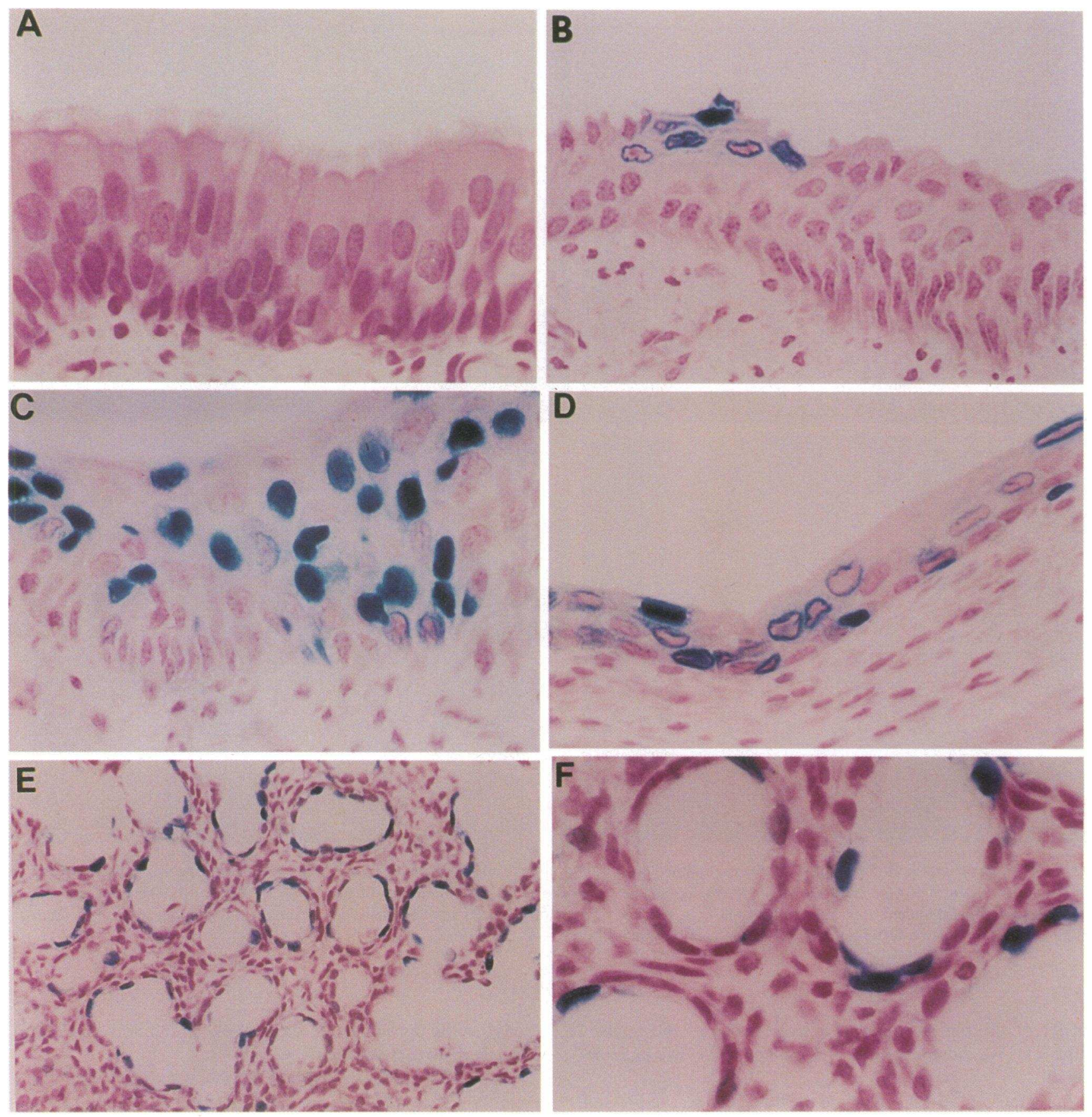

Figure 4. Expression of the lacZ gene in fetal lamb pulmonary epithelia $72 \mathrm{~h}$ after adenoviral-mediated gene transfer. $(A)$ Control tracheal epithelium showing ciliated and nonciliated surface cells and basal cells with no evidence of transgene expression, $\times 1,000$. $(B)$ Tracheal epithelium from fetus that received Ad2/CMV- $\beta$ Gal via a tracheal catheter, $\times 1,000$. Multiple $\beta \mathrm{Gal}$-positive cells are seen as well as loss of cilia and signs of reactive hyperplasia. $(C)$ Area of tracheal epithelium from experimental animal showing loss of cilia and reactive hyperplasia in an area of prominent transgene expression, $\times 1,000$. $(D)$ View of tracheal epithelium with many $\beta$ Gal-positive cells, $\times 1,000$. Reactive changes, squamous metaplasia, and loss of cilia are noted. $(E)$ Sections of distal pulmonary epithelium from Ad2/CMV- $\beta \mathrm{Gal}$-treated fetus demonstrating diffuse epithelial staining, $\times 400$. $(F)$ Distal pulmonary epithelium from experimental lamb showing frequent $\beta$ Gal-positive cells and no evidence of morphologic changes, $\times 1,000$.

cDNA to the fetus. We used RT-PCR to determine if the cDNA was transcribed after administration of Ad2/CFTR-2. As shown in Fig. 5, the Ad2/CFTR-2-treated fetus expressed CFTR mRNA in the lung $3 \mathrm{~d}$ after tracheal instillation.

A concern with viral-mediated gene delivery approaches is the potential for the host to develop an immune response to the vector. Hematoxylin and eosin sections were prepared, and we looked for evidence of cellular immune responses in tissues from all experimental time points (Fig. 6). $3 \mathrm{~d}$ after instillation, sections from the proximal airways and distal lung parenchyma of infected animals and controls showed no evidence of perivascular, interstitial, or intraluminal mononuclear or polymorpho- 
Table I. Percentage of $\beta$ Gal-positive Cells in Trachea and Lung after Ad2/CMV- $\beta$ Gal Administration

\begin{tabular}{lrccc}
\hline & & & \multicolumn{2}{c}{ Percentage of $\beta$ Gal-positive cells } \\
\cline { 5 - 5 } $\begin{array}{l}\text { Duration of } \\
\text { experiment }\end{array}$ & $\begin{array}{c}\text { Volume } \\
\text { instilled }\end{array}$ & $\begin{array}{l}\text { Balloon } \\
\text { catheter }\end{array}$ & Trachea & Lung \\
\hline $3 \mathrm{~d} \mathrm{(1)}$ & $2 \mathrm{ml}$ & - & $1.6(<1-5)$ & 0 \\
$3 \mathrm{~d}(1)$ & $2 \mathrm{ml}$ & + & $18.0(7-28)$ & $<1$ \\
$3-4 \mathrm{~d} \mathrm{(2)}$ & $20 \mathrm{ml}$ & + & $17.8(3-35)$ & $4.0(1-12)$ \\
$>7 \mathrm{~d}(4)$ & $20 \mathrm{ml}$ & + & $<1$ & $<1$ \\
Control (5) & $20 \mathrm{ml}$ & + & 0 & 0 \\
\hline
\end{tabular}

Fetal lambs received recombinant adenovirus via transtracheal needle injection or balloon-tipped catheter in a volume of 2 or $20 \mathrm{ml}$ as noted. The percentage of $\beta \mathrm{Gal}$-positive cells was determined by counting 2,000 cells from each of 3 different tracheal regions $(6,000$ cells/animal). Trachea data are mean and (range) of cell counts from the three different regions. The percentage of $\beta \mathrm{Gal}$-positive lung cells was determined by counting 2,000 cells from each of 2 different regions $(4,000$ cells/animal). Lung data are mean and (range) of cell counts from the different regions. Cell counts from lung include cells in the epithelial of the conducting airways and distal lung. The number of animals in each experimental condition is shown in parentheses. Control tissues showed no blue cells.

nuclear cell infiltrates. In contrast, at 7 and $8 \mathrm{~d}$ after gene transfer, hematoxylin and eosin-stained tissues from adenoviral-treated fetuses exhibited significant cellular infiltrates (Fig. 6 ). The infiltrates were predominantly mononuclear cells in an interstitial, perivascular, and luminal distribution. Polymorphonuclear cells were seen at a lower frequency. The intensity of this inflammatory response was variable, with some areas having few cells present and others showing intense inflammation. This presumably reflects unequal distribution of the viral suspension within the lung at the time of instillation. Occasional blue-staining cells were observed in the lumens, possibly representing shed epithelia. Coincident with the inflammatory response, loss of transgene expression was noted. At 7 and 8 d after lacZ gene transfer, no blue-stained cells were visible macroscopically or microscopically in glycomethacrylate-embedded sections. Less than $1 \%$ of the pulmonary epithelial cells stained blue with X-gal on the more sensitive frozen sections of the tissues, a frequency strikingly less than at days 3 or 4 (Table I). Similarly, in one experiment of 2-wk duration, no blue-stained cells were visible macro- or microscopically except in frozen sections (Fig. 5). Inflammatory cells were present in a distribution similar to the 1-wk experiment, although the density of the infiltrates was less (data not shown).

Tracheal specimens were examined from the 7-, 8-, and 14d time points to assess the evolution of the reactive changes noted at $3 \mathrm{~d}$. While no blue cells were present, areas of reactive hyperplasia were noted at a lower frequency than at days 3 and 4 , suggesting that this process was resolving (data not shown).

To characterize the immune effector cells present in the lung, we performed immunohistochemistry using specific monoclonal antibodies against granulocyte/macrophage, CD4, CD8, and IgM markers (Fig. 6). At 3 and $4 \mathrm{~d}$ after infection, granulocyte/macrophage, CD4, CD8, and IgM marker-positive cells were seen more frequently in the experimental animals than littermate controls. At 7 and $8 \mathrm{~d}$ after infection, a marked immune response was seen consisting primarily of CD4, CD8positive cells in addition to IgM and granulocyte/macrophagemarker positive cells. At the same time viral-treated animals, but not the littermate controls, developed serologic evidence of antiadenoviral antibody production by ELISA assay (data not shown). The antibodies detected are of fetal origin as the ovine placenta is impermeable to maternal antibodies (28). A similar inflammatory response was present in the 2 wk experiment, although the number of inflammatory cells was less compared with 1 wk (data not shown). Similar immune effector cells were present in the Ad2/CMV- $\beta$ Gal-and Ad2/CFTR-2treated fetuses.

To determine the stability of the virus in vivo we assayed serial amniotic fluid samples. Fig. $7 A$ shows the time course of viral titers obtained from the amniotic fluid of two animals. Infectious virus was detectable in the amniotic fluid for $3 \mathrm{~d}$ after instillation of Ad2/CMV- $\beta$ Gal and for $2 \mathrm{~d}$ after Ad2/ CFTR-2, and the titers gradually decreased. No recombinant

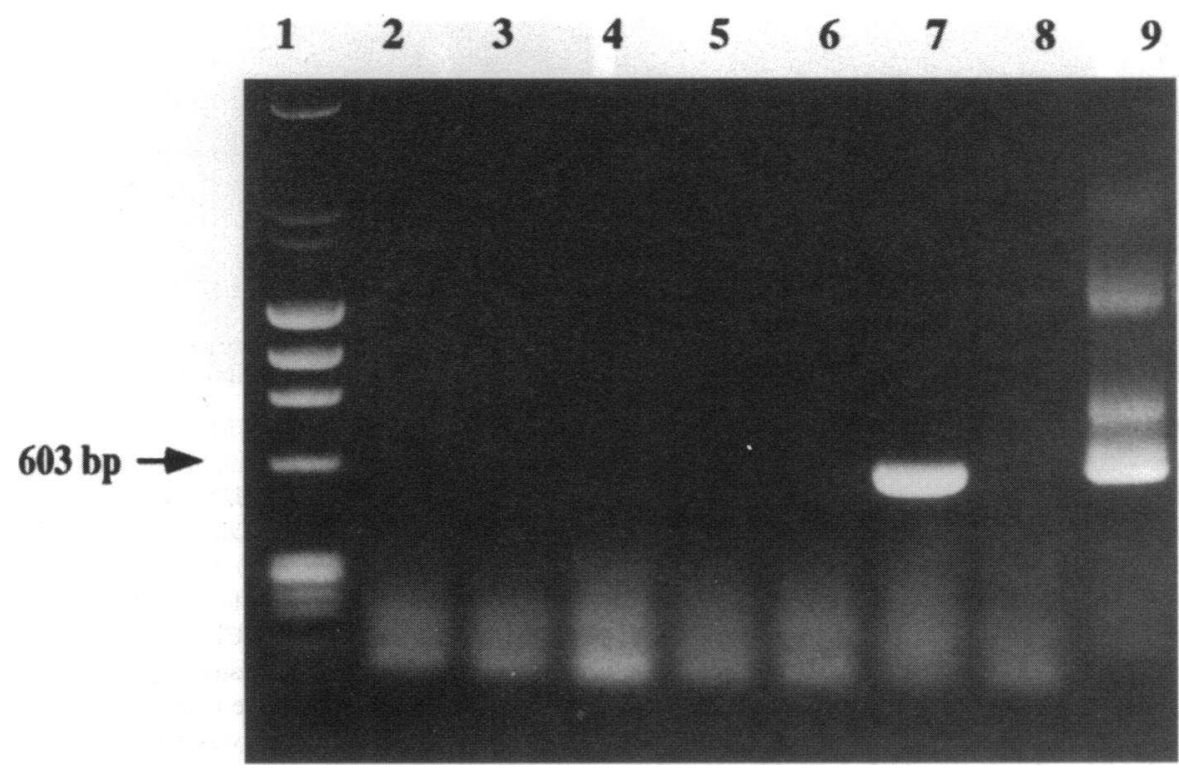

Figure 5. RT-PCR products from lung samples of control and Ad2/CFTR-2-treated fetal lungs. Samples were obtained $3 \mathrm{~d}$ after treatment with the virus. Reverse transcriptase was either absent (lanes 2, 4, 6, and 8 ) or present (lanes 3,5, 7, and 9) during sample preparation. Lane 1 shows DNA markers. Lanes 2 and 3 are $\mathrm{H}_{2} \mathrm{O}$ negative controls for the PCR reaction. Lanes 4 and 5 are samples from a control fetus which received a normal saline tracheal instillation. Lanes 6 and 7 are samples from a fetus treated with Ad2/CFTR-2. The 603-bp product in lane 7 is the size predicted for the $\mathrm{Ad} 2 /$ CFTR-2 product. Lanes 8 and 9 are PCR controls. 

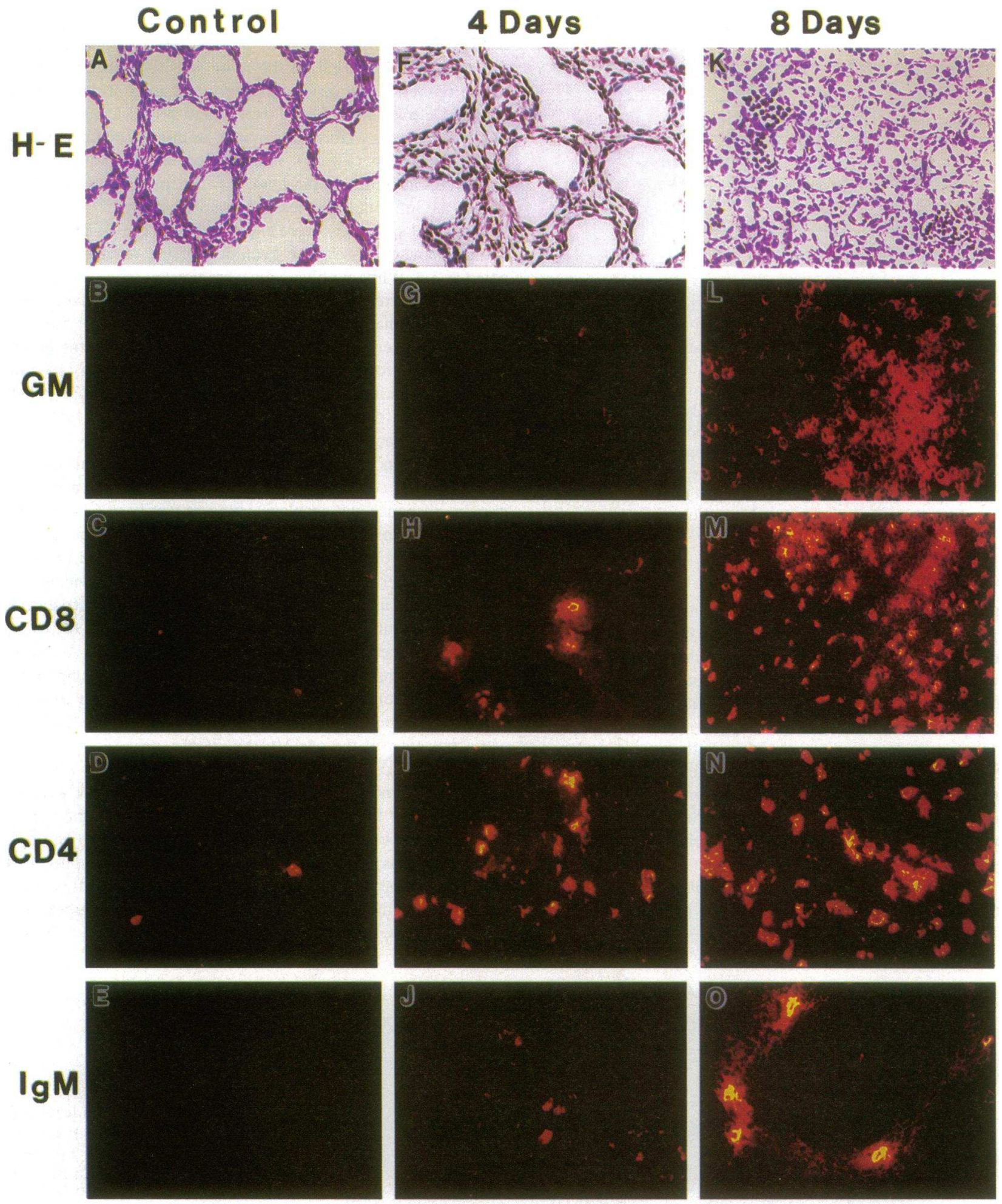

Figure 6. Hematoxylin and eosin (H\&E) staining and immunohistochemistry for immune effector cells from control and Ad2/CMV- $\beta$ Gal-treated fetal lambs. Glycomethacrylate-embedded sections were H \& E stained for inflammatory cell infiltrates. Frozen sections were immunostained to characterize the immune cells. $A-E$ show control lung, $8 \mathrm{~d}$ after saline instillation. $F-J$ show experimental animal $4 \mathrm{~d}$ after Ad2/CMV- $\beta \mathrm{Gal}$ instillation. $K-O$ show experimental animal $8 \mathrm{~d}$ after Ad2/CMV- $\beta$ Gal instillation. $(A) \mathrm{H} \& \mathrm{E}$ stain of control lung, $8 \mathrm{~d}$ after saline instillation; $(B)$ immunostaining for granulocyte/macrophage marker in control; $(C)$ immunostaining for CD-8 lymphocytes in control; $(D)$ immunostaining for CD-4 lymphocytes in control; $(E)$ immunostaining for IgM-positive lymphocytes in control; $(F) \mathrm{H}$ \& E stain of lung $4 \mathrm{~d}$ after Ad2/CMV$\beta \mathrm{Gal}$ instillation; $(G)$ immunostaining for granulocyte/macrophage marker $4 \mathrm{~d}$ after virus instillation; $(H)$ immunostaining for CD-8 lymphocytes $4 \mathrm{~d}$ after virus instillation; $(I)$ immunostaining for CD-4 lymphocytes $4 \mathrm{~d}$ after virus instillation; $(J)$ immunostaining for IgM-positive lymphocytes $4 \mathrm{~d}$ after virus instillation; $(K) \mathrm{H} \& \mathrm{E}$ stain of lung $8 \mathrm{~d}$ after virus instillation; $(L)$ immunostaining for granulocyte/macrophage marker $8 \mathrm{~d}$ after virus instillation; $(M)$ immunostaining for CD-8 lymphocytes $8 \mathrm{~d}$ after virus instillation; $(N)$ immunostaining for CD-4 lymphocytes $8 \mathrm{~d}$ after virus instillation; $(O)$ immunostaining for IgM-positive lymphocytes $8 \mathrm{~d}$ after virus instillation. An increase in immune effector cells is seen in the lungs of virus-treated animals with the most intense infiltrate present at $8 \mathrm{~d}$. 

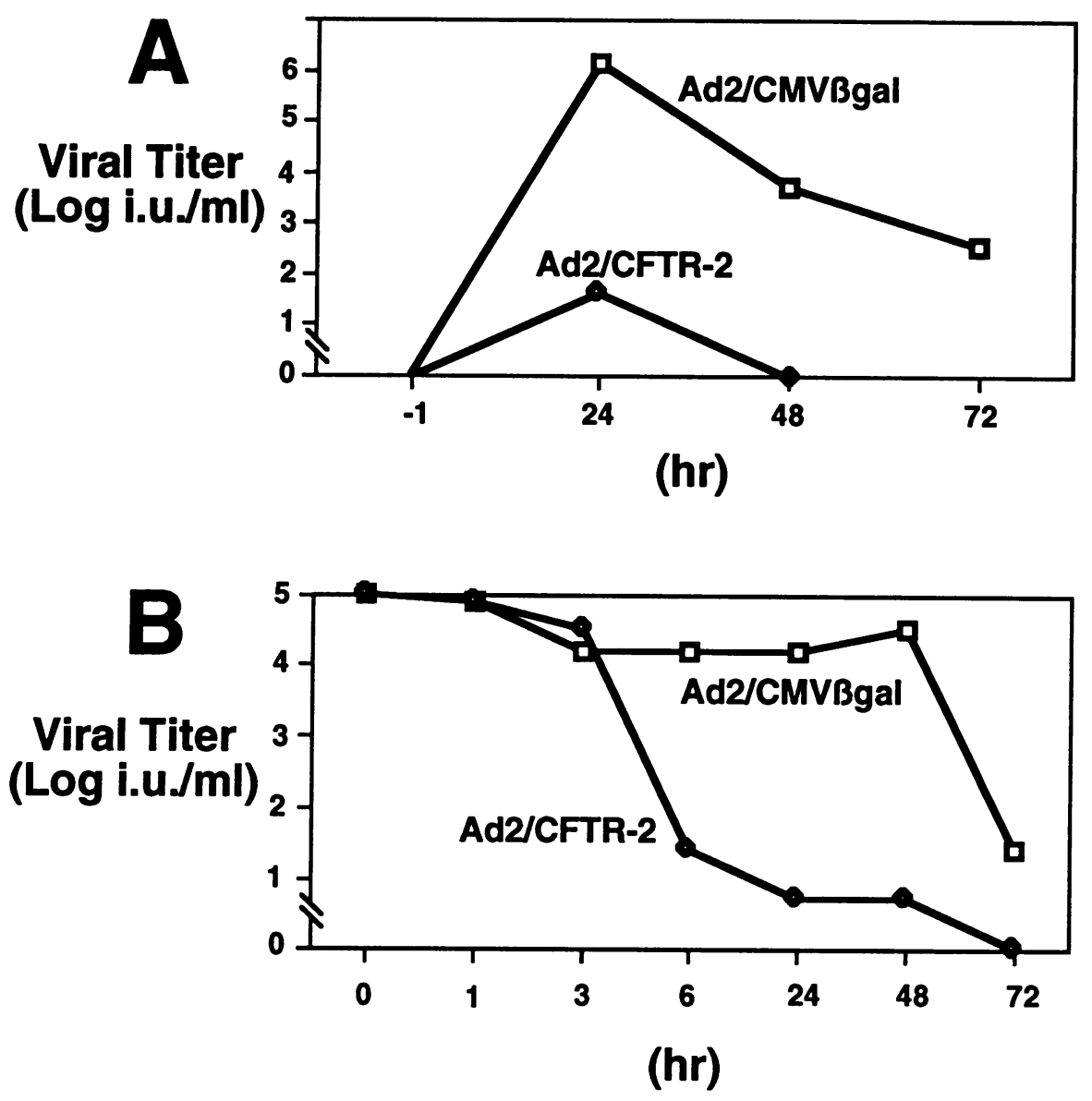

Figure 7. (A) Time course of recombinant adenovirus titers in amniotic fluid of fetal lambs infected with $\mathrm{Ad} 2 / \mathrm{CMV}-\beta \mathrm{Gal}$ or Ad2/CFTR-2. The gradual decline in the number of infectious units over $72 \mathrm{~h}$ suggests that no viral replication occurred. (B) Time course of recombinant adenovirus titers in vitro. Aliquots of $\mathrm{Ad} 2 / \mathrm{CMV}-\beta \mathrm{Gal}$ and $\mathrm{Ad} 2 /$ CFTR-2 at a concentration of $10^{-5} \mathrm{IU} / \mathrm{ml}$ in normal saline were incubated at $37^{\circ} \mathrm{C}$ over $72 \mathrm{~h}$. Figure shows a gradual decline in viral titers that closely resembles the in vivo time course, suggesting the absence of significant immune-mediated viral clearance in the amniotic fluid. virus was detectable in samples from two control amniotic fluid samples. A further concern was the possibility for production of replication competent virus by recombination of $\mathrm{E} 1$ sequences with Ad2/CMV- $\beta$ Gal. However, no growth of replication competent adenovirus was detected in HeLa cell cultures treated with amniotic fluid from the infected animal. Similarly, in vitro cultures of $\mathrm{Ad} 2 / \mathrm{CMV}-\beta \mathrm{Gal}$ and Ad2/CFTR-2 were carried out in normal saline at $37^{\circ} \mathrm{C}$. As shown in Fig. $7 \mathrm{~B}$, the titers gradually declined over $72 \mathrm{~h}$, closely resembling the in vivo time course, suggesting the absence of significant immunemediated viral clearance in the amniotic fluid. Amniotic fluid samples from the beginning and end of 31 -wk experiments and 1 2-wk experiment were also titered. Recombinant virus was detected at $7 \mathrm{~d}$ after virus instillation $\left(6.3 \times 10^{10} \mathrm{IU}\right)$ in one experiment; in the others no virus was detected.

\section{Discussion}

These results demonstrate in murine, ovine, and human models that a replication-defective adenoviral vector can direct shortterm protein expression in fetal pulmonary epithelial cells in vitro and in vivo. Similar to reports of adenoviral-mediated gene transfer in adult cotton rats $(10,29)$ and bronchial xenografts (30), we observed that both surface and basal fetal epithelial cell types incorporated the transgene. The nonciliated cuboidal cells of the distal pulmonary epithelium also expressed the lacZ gene in vitro and in vivo. Little evidence of transgene expression in submucosal glands was seen in the fetal animals in this study. Two unexpected results were noted. First, the fetal lamb airway epithelial cells developed acute morphologic changes 3 and $4 \mathrm{~d}$ after gene transfer. Second, 1 wk after gene transfer, a significant inflammatory response occurred which was temporally associated with loss of gene expression.

Previous reports of adenoviral-mediated gene transfer have focused on gene delivery to adult animals or humans $(2,10)$. The rationale for the present studies was the notion that a fetus might be an immune tolerant host for adenoviral-mediated gene transfer to the lung. Studies of the ontogeny of immunity in human and other mammalian fetuses document that the fetal immune system has both qualitative and quantitative differences in the ability to mount $\mathrm{T}$ and $\mathrm{B}$ lymphocyte-mediated responses to a variety of infectious agents $(28,31,32)$. In the human fetus, B lymphocytes are first detected beginning at 9 wk of gestation, and similarly $\mathrm{T}$ lymphocytes are present by 10-12 wk of gestation (31). With appropriate stimulation human fetal cells may produce antibodies or show functional $\mathrm{T}$ cell responses, while in other circumstances they exhibit tolerance to antigenic challenges. Similarly, while fetal sheep may exhibit immunologic tolerance under some circumstances, humoral and cell-mediated immune responses are also well documented in vivo (32).

While pulmonary epithelial cell gene transfer with recombinant adenoviruses is effective in some short-term studies (2, 10,33 ), recent reports suggest that dose-dependent immune responses limit the duration of gene expression using these vectors $(8,11,34)$. Yang and colleagues (34) found that low- 
level viral gene expression occurs with liver-directed gene transfer using an E1-deleted adenovirus. Their findings suggest that a virus-specific cellular immune response may lead to the destruction of the genetically modified hepatocytes (34). Further studies using mice deficient in $\mathrm{CD}^{+}$lymphocytes are consistent with the hypothesis that MHC class I-restricted CD8 ${ }^{+}$ cytolytic $T$ cells are the primary immune effectors causing loss of transgene expression in this model (11). Gene transfer with recombinant adenoviruses has also been associated with stimulation of the humoral immune system and production of neutralizing antibodies (10).

Unexpectedly, gene transfer to the large airways in the fetal lamb was associated with morphologic changes of reactive hyperplasia and squamous metaplasia in areas of transgene expression 3 and $4 \mathrm{~d}$ after gene transfer. To our knowledge the morphological changes in many tracheal epithelial cells incorporating the transgene $3 \mathrm{~d}$ after infection have not been observed before. These nonspecific changes of cellular hyperplasia and squamous metaplasia appeared reactive, presumably reflecting a cellular response to the viral infection. Similar morphologic changes were seen in aimals that received the CFTR vector Ad2/CFTR-2, indicating that this response is unlikely to be due to the expression of $\beta$-galactosidase. Temporally these changes preceded the inflammatory cell infiltrates that were seen 1 wk after gene transfer. These morphologic changes were not observed in cultured rat or human explants, suggesting either that the findings are species specific or that they are due to factors only present in vivo.

There are several possible explanations for this finding. The first is that viral antigens or viral gene expression and protein production stimulate cell growth and differentiation. Low levels of some adenoviral early and late gene products (E4 and L5) may be expressed by the recombinant virus, and these gene products could modulate cell growth (1). Bronchial xenografts infected with an E1-and E3-deleted adenovirus showed low levels of viral fiber protein production and E2a gene product (30). We also observed low levels of E2a expression by Northern blotting in the lungs of adenoviral-treated fetuses (our unpublished observation ). It is also possible that host factors could substitute for deleted viral products and allow viral protein production. This has been demonstrated in the case of E1a-deleted adenoviruses in HepG2 cells where NF-IL6 acts as a sequencespecific cellular nuclear factor regulating E1a-responsive genes in the absence of E1a $(35,36)$. Second, it is possible that host responses, such as the release of cytokines in response to adenovirus administration, might produce these reactive changes. In a mouse model of adenovirus pneumonia, infection with type 5 adenovirus was associated with the production of tumor necrosis factor- $\alpha$ and interleukins 1 and 6 (37). Respiratory syncytial virus infection of human nasal epithelia stimulates secretion of interleukin 8 (38). Further evaluation for the expression of viral gene products and cytokines may help clarify these findings.

Several findings show that the fetal lamb mounted both humoral and cellular immune responses to the recombinant adenovirus. The fetuses developed antiadenoviral antibodies by 1 wk after infection. Furthermore, they were specific to the viral infection as they were absent in littermate controls. Of note, the antibodies detected were of fetal origin, as maternal antibodies do not cross the ovine placenta (28). This result contrasts with data in neonatal mice in which long-term expression has been observed (12). Characterization of the interstitial, perivas- cular, and intraluminal inflammatory response showed the presence of CD4, CD8, IgM, and granulocyte/macrophage markerpositive immune effector cells. Similar inflammatory responses were seen with both Ad2/CMV- $\beta$ Gal and Ad2/CFTR-2, suggesting that the response was not due to recombinant protein expression. The temporal association between the influx of immune effector cells and the loss of transgene expression implicates these cells in the process. The cellular characteristics and timing of the inflammatory cell infiltrates in this study are consistent with at least part of the loss of gene expression being due to destruction of infected cells by cytotoxic $\mathrm{T}$ lymphocytes as reported recently by Wilson and colleagues (11). Studies of genetically altered sheep or specific suppression of $\mathrm{T}$ and $\mathrm{B}$ cell lymphocyte populations would be required to prove this hypothesis.

Surprisingly, we found that although the titers declined, live virus persisted in the amniotic fluid for as long as $\mathbf{7 ~ d ~ a f t e r}$ tracheal instillation. This suggests that the fluid-filled amniotic environment supports the persistence of the nonreplicating virus. Engelhardt and colleagues reported detection of live virus for up to $24 \mathrm{~d}$ in effluents from bronchial xenografts treated with recombinant adenovirus (30).

A potential advantage of fetal gene transfer is the possibility of permanently correcting a genetic defect early in life, before irreversible organ damage occurs. Since the total number of epithelial cells in the fetal lung is significantly less, it is possible that fewer cells would need to be corrected by gene transfer in the fetus. While adenovirus can transfer genes to cells regardless of their proliferative state, the frequency of adenoviral integration into chromosomal DNA is very low, and gene expression is expected to be episomal and transient. Gene transfer to the pulmonary epithelium of the fetus might be particularly advantageous using a vector that integrates into the host genome (retrovirus or adeno-associated virus). This might allow passage of the transgene from progenitor to daughter cells, thereby increasing the population of corrected cells in the lung.

There are several conditions where gene transfer to the somatic cells of the fetal or neonatal lung might have applications. First, transfer of surfactant protein genes or antioxidant genes to the lung of the preterm infant could enhance surfactant production and protect the pulmonary epithelium from oxygeninduced lung injury associated with the treatment of neonatal respiratory distress syndrome (39). Second, surfactant protein B (SP-B) deficiency, a lung disease of infants associated with mutations in the SP-B gene and absence of SP-B mRNA and protein, may be amenable to gene therapy in the fetus or neonate $(40,41)$. Third, the perinatal transition to air breathing is facilitated by active absorption of sodium through amiloride-sensitive epithelial sodium channels (42). Maladaptions of this process may contribute to lung disease in premature and term infants (43); such problems might be addressed by introducing the epithelial sodium channel genes into the lung of the infant (44, 45 ). Fourth, it may be advantageous to begin CF gene therapy early in life, prenatally or neonatally, to prevent the onset and progression of chronic lung disease. There is now evidence that infants with CF have pulmonary inflammation and altered lung function in infancy before they develop clinical symptoms of respiratory disease or are colonized with bacteria $(46,47)$. Finally, vector-mediated gene transfer may be a useful technique to study lung cell lineage and the developmental regulation of genes introduced into the fetal lung.

In summary, while a replication-defective adenoviral vector 
was effective for short-term gene transfer to fetal pulmonary epithelia in vitro, gene transfer in vivo in fetal lambs was shortlived and associated with significant cellular and humoral immune responses. These results suggest that current E1-deleted adenoviral vectors are ineffective for gene transfer in the fetus. Several strategies may be proposed to circumvent the fetal immune response to the vector and deserve further study. Additional deletions or alterations of the viral backbone to reduce viral protein expression may blunt the fetal immune response. It may also be possible to tolerize a fetus by administering lower doses of virus, perhaps at an earlier developmental time point. The fetal immune response could be minimized or prevented using pharmacologic immunosuppressive agents or specific monoclonal antibodies against immune effector cells. Successful gene transfer to the fetal or neonatal lung will require further modifications of the adenoviral vector system or alternative vector approaches.

\section{Acknowledgments}

We thank Tim Joseph, Oliva McWeeny, Jeff Otto, Aurita Puga, Bruce Smith, and Kathy Walter for excellent technical assistance. We especially thank Deanna Peterson for assistance with RT-PCR and Dr. John Hopkins for technical advice and for providing sheep anti-CD4 and -CD8 antibodies. We thank Dr. Jeanne Snyder in the Department of Anatomy and Drs. Stephen Bonsib, Stephen Raab, and Garvan Browne in the Department of Pathology for reviewing and commenting on the morphology of the tissues.

Gary A. Koretzky is an Established Investigator of the American Heart Association. This work was supported in part by the Howard Hughes Medical Institute, grants from the National Institutes of Health (HL-51670 to M. J. Welsh and HL-02767), and the Cystic Fibrosis Foundation (P. B. McCray).

\section{References}

1. Rich, D. P., L. A. Couture, L. M. Cardoza, V. M. Guiggio, D. Armentano, P. C. Espino, K. Hehir, M. J. Welsh, A. E. Smith, and R. J. Gregory. 1993 Development and analysis of recombinant adenovirus for gene therapy of cystic fibrosis. Hum. Gene Ther, 4:461-476.

2. Rosenfeld, M. A., K. Yoshimura, B. C. Trapnell, Y. Koichi, E. R. Rosenthal W. Dalemans, M. Fukayama, J. Bargon, L. E. Stier, L. D. Stratford-Perricaudet, et al. 1992. In vivo transfer of the human cystic fibrosis transmembrane conductance regulator gene to the airway epithelium. Cell. 68:143-155.

3. Engelhardt, J. F., J. R. Yankaskas, and J. M. Wilson. 1992. In vivo retrovira gene transfer into human bronchial epithelia of xenografts. I. Clin. Invest. 90:2598-2607.

4. Rosenfeld, M. A., W. Siegfried, K. Yoshimura, K. Yoneyama, M. Fukayama, L. E. Stier, P. K. Paakko, P. Gilardi, L. D. Stratford-Perricaudet, M. Perricaudet, et al. 1991. Adenovirus-mediated transfer of a recombinant $\alpha$-antitrypsin gene to the lung epithelium in vivo. Science (Wash. DC). 252:431-434.

5. Yang, Y., S. E. Raper, J. A. Cohn, J. F. Engelhardt, and J. M. Wilson. 1993. An approach for treating the hepatobiliary disease of cystic fibrosis by somatic gene transfer. Proc. Natl. Acad. Sci. USA. 90:4601-4605.

6. Kay, M. A., S. Rothenberg, C. N. Landen, D. A. Bellinger, F. Leland, C. Toman, M. Finegold, A. R. Thompson, M. S. Read, K. M. Brinkhous, and S. L. C. Woo. 1993. In vivo gene therapy of hemophilia B: sustained partial correction in factor IX-deficient dogs. Science (Wash. DC). 262:117-119.

7. Zabner, J., L. A. Couture, R. J. Gregory, S. M. Graham, A. E. Smith, and M. J. Welsh. 1993. Adenovirus-mediated gene transfer transiently corrects the chloride transport defect in nasal epithelia of patients with cystic fibrosis. Cell. 75:207-216.

8. Simon, R. H., J. F. Engelhardt, Y. Yang, M. Zepeda, S. Weber-Pendleton, M. Grossman, and J. M. Wilson. 1993. Adenovirus-mediated transfer of the CFTR gene to lung of nonhuman primates: toxicity study. Hum. Gene Ther. 4:771-780.

9. Yang, Y., F. A. Nunes, K. Berencsi, E. Gonczol, J. F. Engelhardt, and J. M. Wilson. 1994. Inactivation of E2a in recombinant adenoviruses improves the prospect for gene therapy in cystic fibrosis. Nature Genet. 7:362-369.

10. Zabner, J., D. M. Petersen, A. P. Puga, S. M. Graham, M. J. Welsh, L. A. Couture, L. D. Keyes, M. J. Lukason, J. A. St. George, R. J. Gregory, and A. E. Smith. 1994. Safety and efficacy of repetitive adenovirus-mediated transfer of
CFTR cDNA to airway epithelia of primates and cotton rats. Nature Genet. 6:7583.

11. Yang, Y., H. C. J. Ertl, and J. M. Wilson. 1994. MHC class I-restriced cytotoxic $\mathrm{T}$ lymphocytes to viral antigens destroy hepatocytes in mice infected with E1-deleted recombinant adenoviruses. Immunity. 1:433-442.

12. Stratford-Perricaudet, L. D., I. Makeh, M. Perricaudet, and P. Briand. 1992. Widespread long-term gene transfer to mouse skeletal muscles and heart. J. Clin. Invest. 90:626-630.

13. Armentano, D., C. Sookdeo, L. Couture, K. Vincent, L. Cardoza, V. Guiggio, D. Souza, R. Gregory, and A. Smith. 1993. Second generation adenoviruses for gene therapy of CF. Pediatr. Pulmonol. 9 (Suppl.):143a. (Abstr.)

14. Davis, W. C., S. Marusic, H. A. Lewin, G. A. Splitter, L. E. Perryman, T. C. McGuire, and J. R. Gorham. 1987. The development and analysis of species specific and cross reactive monoclonal antibodies to leukocyte differentiation antigens and antigens of the major histocompatibility complex for use in the study of the immune system in cattle and other species. Vet. Immunol. Immunopathol. 15:337-376.

15. Hopkins, J., A. Ross, and B. M. Dutia. 1993. 5.1 Summary of workshop findings of leukocyte antigens in sheep. Vet. Immunol. Immunopathol. 39:49-59.

16. Davis, W. C., Y. H. Park, L. P. Perryman, and R. A. Larsen. 1988. NonT/ nonB cells are a major antigenically distinct population of cells in ruminants. FASEB (Fed. Am. Soc. Exp. Biol.) J. 2:465a. (Abstr.)

17. Chomczynski, P., and N. Sacchi. 1987. Single-step method of RNA isolation by acid guanidinium thiocyanate-phenol-chloroform extraction. Anal. Biochem. 162:156-159.

18. Massoud, A. S., H. S. Sekhon, A. Rotschild, and W. M. Thurlbeck. 1992. The in vitro effect of triamcinolone acetonide on branching morphogenesis in the fetal rat lung. Pediatr. Pulmonol. 14:28-36.

19. McCray, P. B., Jr., J. D. Bettencourt, J. Bastacky, G. M. Denning, and M. J. Welsh. 1993. Expression of CFTR and a cAMP-stimulated chloride secretory current in cultured human fetal alveolar epithelial cells. Am. J. Respir. Cell Mol. Biol. 9:578-585.

20. Papaioannou, V. 1990. In utero manipulations. In Postimplantation Mammalian Embryos. A. J. Copp and D. L. Cockroft, editors. IRL Press, New York 61-80.

21. Trevino, C., R. Anderson, and K. Muneoka. 1993. 3T3 cell integration and differentiative potential during limb development in the mouse. Dev. Biol. 155:38-45.

22. Artinger, K. B., and M. Bronner-Fraser. 1992. Partial restriction in the developmental potential of late emigrating avian neural crest cells. Dev. Biol. 149:149-157.

23. Robillard, J. E., and R. E. Weitzman. 1980. Developmental aspects of the fetal renal response to exogenous arginine vasopressin. Am. J. Physiol. 238:F407F414.

24. Snyder, J. M., J. M. Johnston, and C. R. Mendelson. 1981. Differentiation of type II cells of human fetal lung in vitro. Cell Tissue Res. 220:17-25.

25. Harding, R. 1991. Fetal breathing movements. In The Lung: Scientific Foundations. R. G. Crystal and J. B. West, editors. Raven Press Ltd., New York. $1655-1663$.

26. Leaver, L. T. 1991. Anatomy and embryology. In Pediatric Gastrointestinal Disease. W. A. Walker, P. R. Durie, J. R. Hamilton, J. A. Walker-Smith, and J. B. Watkins, editors. B. C. Decker, Inc., Philadelphia. 195-216.

27. Engelhardt, J. F., J. R. Yankaskas, S. A. Ernst, Y. Yang, C. R. Marino, R. C. Boucher, J. A. Cohn, and J. A. Wilson. 1992. Submucosal glands are the predominant site of CFTR expression in the human bronchus. Nature Genetics. 2:240-248.

28. Campbell, S. G., M. J. Siegel, and B. J. Knowlton. 1977. Sheep immunoglobulins and their transmission to the neonatal lamb. NZ Vet. J. 25:361-365.

29. Mastrangeli, A., C. Danel, M. A. Rosenfeld, L. D. Stratford-Perricaudet, M. Perricaudet, A. Pavirani, J.-P. Lecocq, and R. G. Crystal. 1993. Diversity of airway epithelial cell targets for in vivo recombinant adenovirus-mediated gene transfer. J. Clin. Invest. 91:225-234.

30. Engelhardt, J. F., Y. Yang, L. D. Stratford-Perricaudet, E. D. Allen, K. Kozarsky, M. Perricaudet, J. R. Yankaskas, and J. M. Wilson. 1993. Direct gene transfer of human CFTR into human bronchial epithelia of xenografts with E1deleted adenoviruses. Nature Genet. 4:27-34.

31. Lawton, A. R., and M. D. Cooper. 1989. Ontogeny of immunity. In Immunologic Disorders in Infants and Children. R. Stiehm, editor. Saunders Publishing Company, Philadelphia. 1-14.

32. Miyasaka, M., and B. Morris. 1988. The ontogeny of the lymphoid system and immune responsiveness in sheep. Prog. Vet. Microbiol. Immunol. 4:21-55.

33. Englehardt, J. F., R. H. Simon, Y. Yang, M. Zepeda, S. Weber-Pendleton, B. Doranz, M. Grossman, and J. M. Wilson. 1993. Adenovirus-mediated transfer of the CFTR gene to lung of nonhuman primates: biological efficacy study. Hum. Gene Ther. 4:759-769.

34. Yang, Y., F. A. Nunes, K. Berencsi, E. E. Furth, E. Gonczol, and J. M. Wilson. 1994. Cellular immunity to viral antigens limits E1-deleted adenoviruses for gene therapy. Proc. Natl. Acad. Sci. USA. 91:4407-4411.

35. Spergel, J. M., and S. Chen-Kiang. 1991. Interleukin-6 enhances a cellular 
activity that functionally substitutes for E1A protein in transactivation. Proc. Natl. Acad. Sci. USA. 88:6472-6476.

36. Spergel, J. M., W. Hsu, S. Akira, B. Thimmappaya, T. Kishimoto, and S. Chen-Kiang. 1992. NF-IL6, a member of the C/EBP family, regulates E1Aresponsive promoters in the absence of E1A. J. Virol. 66:1021-1030.

37. Ginsberg, H. S., L. L. Moldawer, P. B. Sehgal, M. Redington, P. L. Kilian, R. M. Chanock, and G. A. Prince. 1991. A mouse model for investigating the molecular pathogenesis of adenovirus pneumonia. Proc. Natl. Acad. Sci. USA. 88:1651-1655.

38. Becker, S., H. S. Koren, and D. C. Henke. 1993. Interleukin-8 expression in normal nasal epithelium and its modulation by infection with respiratory syncytial virus and cytokines tumor necrosis factor, interleukin-1, and interleukin-6. Am. J. Respir. Cell Mol. Biol. 8:20-27.

39. Wispe, J. R., B. B. Warner, J. C. Clark, C. R. Dey, J. Neuman, S. W. Glasser, J. D. Crapo, L.-Y. Chang, and J. A. Whitsett. 1992. Human Mn-superoxide dismutase in pulmonary epithelial cells of transgenic mice confers protection from oxygen injury. J. Biol. Chem. 267:23937-23941.

40. Nogee, L. M., D. E. deMello, L. P. Dehner, and H. R. Colten. 1993. Brief report: deficiency of pulmonary surfactant protein B in congenital alveolar proteinosis. N. Engl. J. Med. 328:406-410.

41. Nogee, L. M., G. Garnier, H. C. Dietz, L. Singer, A. M. Murphy, D. E.
deMello, and H. R. Colten. 1994. A mutation in the surfactant protein B gene responsible for fatal neonatal respiratory disease in multiple kindreds. J. Clin. Invest. 93:1860-1863.

42. Strang, L. B. 1991. Fetal lung liquid: secretion and reabsorption. Physiol. Rev. 71:991-1016.

43. Gowen, C. W., Jr., E. E. Lawson, J. Gingras, R. C. Boucher, J. T. Gatzy, and M. R. Knowles. 1988. Electrical potential difference and ion transport across nasal epithelium of term neonates: correlation with mode of delivery, transient tachypnea of the newborn, and respiratory rate. J. Pediatr. 113:121-127.

44. Canessa, C. M., J.-D. Horisberger, and B. C. Rossier. 1993. Epithelial sodium channel related to proteins involved in neurodegeneration. Nature (Lond.). 361:467-470.

45. Canessa, C. M., L. Schild, G. Buell, B. Thorens, I. Gautschi, J.-D. Horisberger, and B. C. Rossier. 1994. Amiloride-sensitive epithelial $\mathrm{Na}^{+}$channel is made of three homologous subunits. Nature (Lond.). 367:463-467.

46. Balough, K., R. Fick, Jr., M. Weinberger, M. McCubbin, and R. Ahrens. 1992. Inflammation in early cystic fibrosis lung lesion: lack of correlation with infection. Am. Rev. Respir. Dis. 145:689a.(Abstr.)

47. Khan, T. Z., J. S. Wagener, D. W. H. Riches, and F. J. Accurso. 1993. Increased interleukin- 8 levels and gene expression by pulmonary macrophages in bronchoalveolar lavage fluid from infants with cystic fibrosis. Clin. Res. 41:2a. (Abstr.) 